\title{
Long term survival of a metastatic patient with pancreatic adenocarcinoma: a rare case report and review of the literature
}

\author{
Uzun süreli sağkalım gösteren metastatik pankreas adenokanserli olgu: \\ Nadir bir olgu ve literatürün taranması
}

\author{
Mustafa DEĞirmenCi' ${ }^{1}$, Umut VAROL ${ }^{2}$, Alp ÖZGÜZER ${ }^{3}$, Mehmet BOZKURT ${ }^{4}$, Canfeza SEZGiN ${ }^{5}$ \\ 'Department of Medical Oncology, İzmir Tepecik Training and Research Hospital, İmir; \\ ${ }^{2}$ Department of Medical Oncology, İzmir Katip Çelebi University Atatürk Training and Research Hospital, Izmir; \\ ${ }^{3}$ Department of Pathology, İmir Tepecik Tepecik Training and Research Hospital, Izmir; \\ ${ }^{4}$ Department of Radiology, Izmir Tepecik Training and Research, Izmir; \\ ${ }^{5}$ Department of Medical Oncology, Ege University Tülay Aktaş Oncology Hospital, İzmir
}

\begin{abstract}
Despite recent advances in therapeutics, the prognosis of patients with advanced pancreatic cancer has remained poor. Median survival of patient is 3-6 months and five year survival rate is less than $5 \%$. We report a case of fifty-five-yearold male with complaints of abdominal pain and weight loss. Patient was diagnosed as pancreas adenocarcinoma with multiple hepatic metastases. Then, the patient received gemcitabine $1250 \mathrm{mg} / \mathrm{m}^{2}$ at day 1 and 8 ; cisplatin $80 \mathrm{mg} / \mathrm{m}^{2}$ at day 1 and a cycle of therapy was defined as 21 days. After six cycles, partial response was achieved, but associated with grade 3 neutropenia. So, cisplatin was stopped and patient was treated with gemcitabine monotherapy. After 18 cycles, complete response in hepatic metastases was observed with magnetic resonance imaging. Due to hematologic and renal toxicity, only gemcitabine monotherapy was continued in our patient, but still indicating complete remission in his fifth year.
\end{abstract}

Key words: Metastasis; long-term survival; pancreatic cancer.
Tedavi alanındaki önemli gelişmelere rağmen ileri evre pankreas kanseri olan hastaların prognuzu oldukça kötüdür. Hastaların ortalama yaşam süresi üç-altı aydır ve beş yıl süreli yaşam oranı ise $\% 5$ 'ten azdır. Bu yazıda, karın ağrısı ve kilo kaybı şikayetleri ile başvuran 55 yaşında bir erkek hasta sunuldu. Hastanın çoklu karaciğer metastazı olan pankreas kanseri olduğu saptandı. Takiben hastaya, 21 günde bir gemitabin $1250 \mathrm{mg} / \mathrm{m}^{2}$ birinci ve sekizinci gün; sisplatin $80 \mathrm{mg} /$ $\mathrm{m}^{2}$ birinci gün olan kemoterapi protokolü uygulandı. Altınc1 kür sonunda parsiyel yanıt alındığı, fakat buna üçüncü derece nötropeninin eşlik ettiği saptand. Bu yüzden sisplatin kesildi ve tedaviye tek başına gemsitabin ile devam edildi. 18 siklus sonunda manyetik rezonans görüntüleme ile karaciğer metastazlarının tamamen kaybolduğu görüldü. Hematolojik ve böbrek toksisitesi nedeniyle tedaviye gemsitabin ile devam edilebildi ve beşinci yılın sonunda tam yanıt halen sürmekteydi. Literatürü taradığımızda tam yanıt alınıp uzun süreli sağkalımı olan çok az sayıda olguya rastlanmaktadır.

Anahtar sözcükler: Metastaz; uzun süreli sağkalım; pankreas kanseri.
Pancreatic adenocarcinoma is one of the most aggressive cancers and most patients are diagnosed with advanced or metastatic disease at first presentation. In most cases they developed metastatic disease even if curable resection is applied. For the last 10 years, gemcitabine, an antimetabolite agent, is widely used for the first-line treatment of metastatic pancreatic cancer. To improve the clini-

Correspondence (İletişim): Dr. Umut VAROL. İzmir Katip Çelebi Üniversitesi Atatürk Eğitim ve Araştırma Hastanesi, Tıbbi Onkoloji Bölümü, İzmir, Turkey. Tel: +90 - 232 - 2444444 e-mail (e-posta): varolumut@yahoo.com 

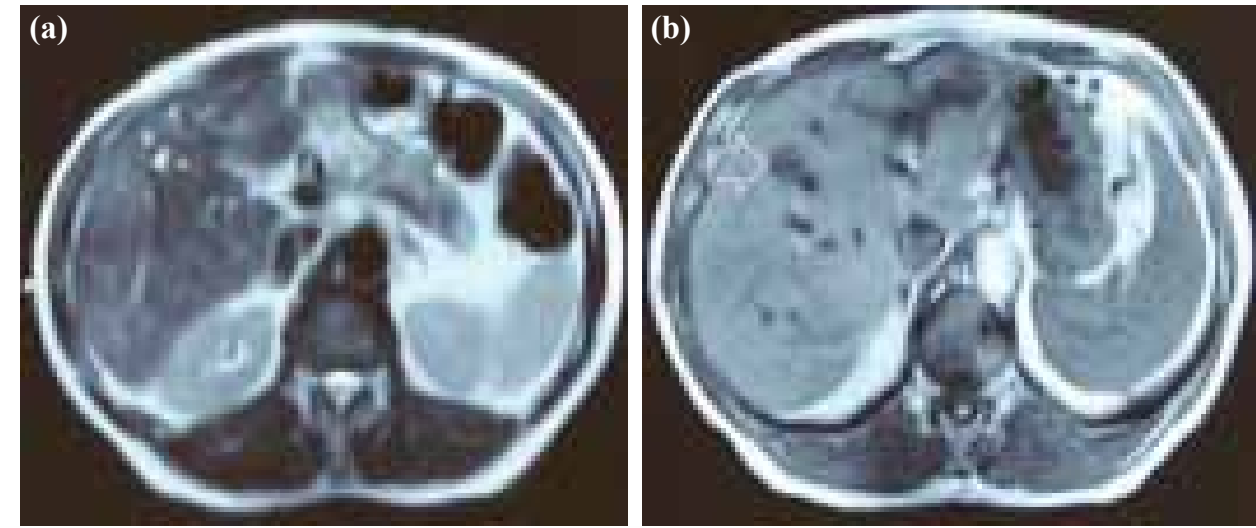

Fig. 1. Abdominal MRI before chemotherapy, hepatic metastases with $3 \mathrm{~cm}$ in greatest diameter were observed.

cal efficacy of gemcitabine, it is frequently used in combinations with platinum analogs, fluorouracil and targeting agents. Cisplatin shows its effect by creating DNA-DNA cross-links and DNA protein cross-links, and it is assumed that resistance developed against gemcitabine is surpassed with cisplatin combination. Here, we report our experience of treating a metastatic pancreatic cancer patient with gemcitabine plus cisplatin. Though rare, long-term survival is sometimes possible even when pancreas cancer has spread.

\section{CASE REPORT}

In May 2008, 55 years old male patient was admitted with complaints of severe abdominal pain, weight loss and loss of appetite. There was no additional disease. In physical examination, blood pressure was $100 / 60 \mathrm{mmHg}$, heart rate was 80 beat/ minute and severe epigastric tenderness was present. In laboratory examinations, liver function tests were moderately high (aspartate aminotransferase: $63 \mathrm{IU} / \mathrm{L}$, alanine aminotransferase: $137 \mathrm{IU} / \mathrm{L})$. No pathologic finding was observed in gastroscopy and colonoscopy. Abdominal magnetic resonance imaging (MRI) scan revealed; lesions consistent with metastasis in all lobes and segments of the liver parenchyma and in large quantities with the largest size of $3 \mathrm{~cm}$, a $2 \mathrm{~cm}$ mass located at the junction of the pancreatic corpus and tail and additionally, regional lymphadenopathies observed in peripancreatic region (Figure 1). Adenocarcinoma of the pancreas was diagnosed by fine needle aspiration biopsy specimen sampled from both pan- creas and hepatic metastasis (Figure 2).

On June 5, 2008, the first chemotherapy was initiated with gemcitabine $1250 \mathrm{mg} / \mathrm{m}^{2} / \mathrm{d} 1,8$ and cisplatin $80 \mathrm{mg} / \mathrm{m}^{2} / \mathrm{d} 1$ and a cycle of therapy was defined as 21 days. After 2 cycles, patient's symptoms were improved and liver function tests were returned to normal range. Following the third cure, partial response was detected in radiologic examination. Combination chemotherapy was associated with hematologic toxicity (grade 3 neutropenia) after 5 cycles and from 6th cycle; patient was treated with single-agent gemcitabine. Response to monotherapy was assessed by radiologic evaluation with 3 months intervals and complete response was ob-

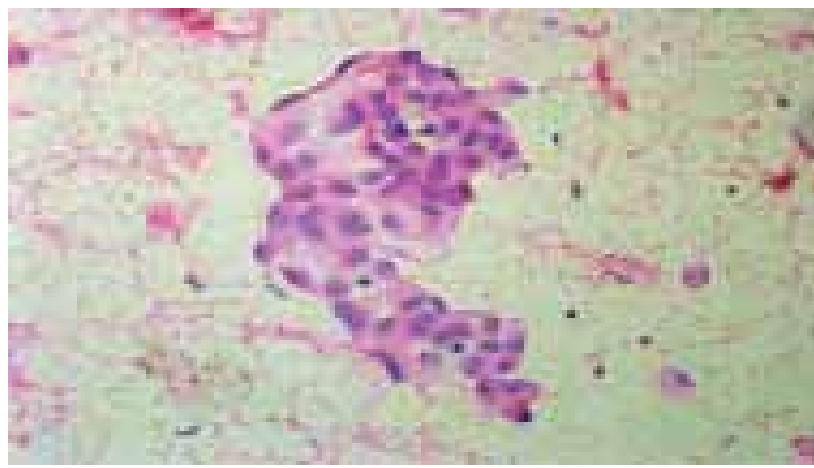

Fig. 2. H\&E staining. Pancreatic Adenocarcinoma: USG guided transabdominal FNAB revealed epitelial three dimentinal clusters with tubulary configurations on a dirty background. Tumor cells have round nuclei with prominant nucleolei, some cytoplasms are vacuolated. Nucleocytoplasmic ratio is moderately high. Cytologic diagnosis is "adenocarcinoma G II". Color figure can be viewed in the online issue, which is available at (www.onkder.org) 

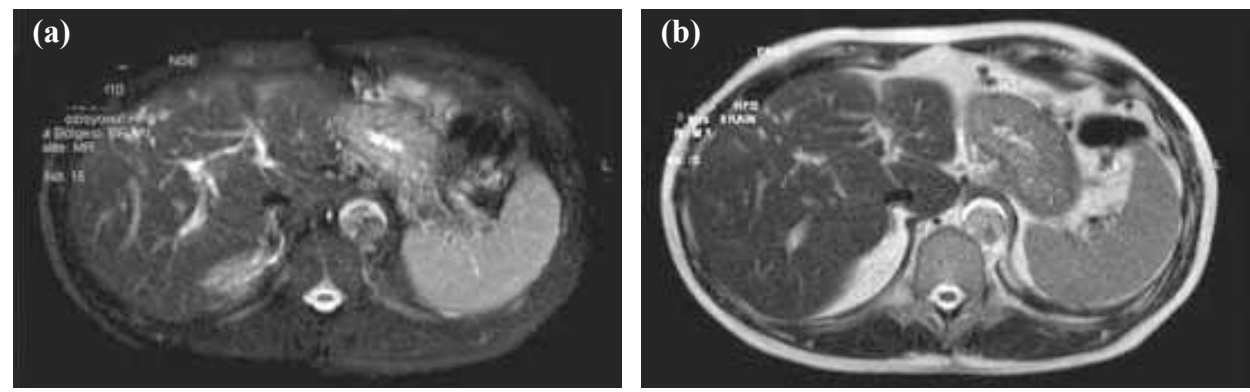

Fig. 3. Abdominal MRI after 18 cycles of chemotherapy, complete disappearance of hepatic metastases.

served in abdominal MRI subsequent to 18th cycle on June 18, 2009. Afterwards, chemotherapy was continued with a $25 \%$ reduction in gemcitabine dose due to grade 2 thrombocytopenia and weightloss. The last $67 \mathrm{th}$ cycle, a dose of $800 \mathrm{mg} /$ day gemcitabine was given to the patient on November 21, 2012. Thereafter, chemotherapy was terminated because of gemcitabine related toxicities such as hypertension and renal toxicity. Patient was still observed as relapse-free. Radiological examinations taken in the last abdominal MRI and PET/CT showed no evidence of metastases and local recurrence (Figure 3). From the time of diagnosis for metastatic pancreatic cancer, patient had received chemotherapy for nearly 5 years and still without evidence of local and metastatic disease.

\section{DISCUSSION}

Metastatic pancreatic cancer patients mostly die from the disease because of its propensity for late presentation with advance stage and resistance to chemotherapy. Less than $25 \%$ of the metastatic patients are associated with significant clinical response. ${ }^{[1]}$ More than 5 years of survival is observed in only a few cases. ${ }^{[2]}$ Perineural invasion, lymphatic and venous infiltration, poor differentiation, peritoneal metastases and tumor size $\geq 2 \mathrm{~cm}$ in diameter are poor prognostic factors. ${ }^{[3]}$ Although poor prognostic factors are well established, limited information is available about the good prognostic factors. Furthermore, we did not know the potential predictor markers that may have a role to identify patients who benefit most from the chemotherapeutic agents.

Systemic chemotherapy with single-agent gemcitabine or gemcitabine-based regimens became standard for patients with advanced pancreatic cancer and proved to be superior to 5-Fluorourasil (5-FU)-based chemotherapy in terms of both clinical response and survival. ${ }^{[4]}$ Combination of gemcitabine and cisplatin are synergistic, and there are many phase III trials comparing this combination with gemcitabine monotherapy. Overall survival and progression-free survival were more favorable in the combination arm, although the difference did not reach to statistical significance..$^{[5,6]}$

In the CONKO-001 study, which established gemcitabine after resection as adjuvant therapy, 54 among 354 patients (15\%) with an overall survival $\geq 5$ years were identified. It was possible to obtain tumor specimens of 39 patients $(72 \%)$ with adenocarcinoma in 38 patients. ${ }^{[7]}$ In a Swedish cancer register analysis, less than $3 \%$ of patients with a histopathologically confirmed diagnosis of pancreatic adenocarcinoma including both early and advanced stage, survived five years or longer. ${ }^{[8]}$ In the literature, there was also a similar pancreatic cancer patient with hepatic metastasis and after pancreaticoduodenectomy successfully treated by S-1 and gemcitabine combination chemotherapy and achieved long-term survival. ${ }^{[9]}$ In another case report with inoperable multiple hepatic metastases, long-term survival for more than 10 years was accomplished with multiple lines of treatment. ${ }^{[10]}$

When we analyzed the aforementioned randomized studies and searched the related articles in literature, we found very few cases that have been reported to have long term survival. Our case indicated long term survival greater than five years although he had multiple hepatic metastatic lesions and poor prognostic features at the time of diag- 
nosis. To date from the time of diagnosis, patient has been symptom and relapse-free for 65 months and complete response is observed for a long period of time. So, our metastatic patient is one of the rare cases in literature and represents a subgroup of pancreatic cancer patients with favorable outcome that may be more responsive to chemotherapy.

\section{REFERENCES}

1. Alberts SR, Townley PM, Goldberg RM, Cha SS, Sargent DJ, Moore DF, et al. Gemcitabine and oxaliplatin for metastatic pancreatic adenocarcinoma: a North Central Cancer Treatment Group phase II study. Ann Oncol 2003;14(4):580-5. CrossRef

2. Shimada K, Kosuge T, Yamamoto J, Yamasaki S, Sakamoto M. Successful outcome after resection of pancreatic cancer with a solitary hepatic metastasis. Hepatogastroenterology 2004;51(56):603-5.

3. Nagakawa T, Sanada H, Inagaki M, Sugama J, Ueno K, Konishi I, et al. Long-term survivors after resection of carcinoma of the head of the pancreas: significance of histologically curative resection. J Hepatobiliary Pancreat Surg 2004;11(6):402-8. CrossRef

4. Burris HA 3rd, Moore MJ, Andersen J, Green MR, Rothenberg ML, Modiano MR, et al. Improvements in survival and clinical benefit with gemcitabine as firstline therapy for patients with advanced pancreas cancer: a randomized trial. J Clin Oncol 1997;15(6):2403-13.

5. Colucci G, Labianca R, Di Costanzo F, Gebbia V,
Cartenì G, Massidda B, et al. Randomized phase III trial of gemcitabine plus cisplatin compared with single-agent gemcitabine as first-line treatment of patients with advanced pancreatic cancer: the GIP-1 study. J Clin Oncol 2010;28(10):1645-51. CrossRef

6. Berlin JD, Catalano P, Thomas JP, Kugler JW, Haller DG, Benson AB 3rd. Phase III study of gemcitabine in combination with fluorouracil versus gemcitabine alone in patients with advanced pancreatic carcinoma: Eastern Cooperative Oncology Group Trial E2297. J Clin Oncol 2002;20(15):3270-5. CrossRef

7. Sinn M, Striefler JK, Sinn BV, Sallmon D, Bischoff S, Stieler JM, et al. Does long-term survival in patients with pancreatic cancer really exist? Results from the CONKO-001 study. J Surg Oncol 2013;108(6):398402. CrossRef

8. Lambe M, Eloranta S, Wigertz A, Blomqvist P. Pancreatic cancer; reporting and long-term survival in Sweden. Acta Oncol 2011;50(8):1220-7. CrossRef

9. Hoshino H, Takeda Y, Nagano H, Nakamori S, Kobayashi S, Eguchi H, et al. A long-term survival case of pancreatic cancer with hepatic metastasis after pancreaticoduodenectomy successfully treated by s- 1 and gemcitabine combination chemotherapy. [Article in Japanese] Gan To Kagaku Ryoho 2009;36(12):241921. [Abstract]

10. Spinelli GP, Zullo A, Romiti A, Di Seri M, Tomao F, Miele E, et al. Long-term survival in metastatic pancreatic cancer. A case report and review of the literature. JOP 2006;7(5):486-91. 